\title{
THE OPERATION OF THE TRADE AGREEMENTS PROGRAM IN OVERCOMING BARRIERS TO HEMISPHERE TRADE
}

\author{
Charles F. Darlington*
}

\section{Theory and Background of Present United States Commercial Policy}

While war raged in Europe and the Orient a most important event of a peaceful nature took place this Fall in the Western Hemisphere. On October I4th there was signed in Buenos Aires a trade agreement between Argentina and the United States, the first commercial agreement or treaty to be concluded between the two countries since $\mathrm{r} 853$.

The signature of the agreement represents the culmination of a long effort by both governments. Argentina, occupying a leading position politically and economically in our own hemisphere, was naturally one of the first countries to be considered when the trade agreements program was begun in 1934. On two occasions since then, in 1936 and again in I939, agreement seemed in sight, but not until this autumn could the differences between the two countries be bridged.

The message addressed by President Roosevelt to Acting President Castillo, and Dr. Castillo's reply, lifted the agreement out of the realm of commerce and stressed its significance in the political relations between the two countries. Both made it clear that they consider that the main importance of the agreement lies not in the trade benefits which the two countries concede to each other but in its contribution to the principle of hemisphere solidarity and cooperation. President Roosevelt predicted that "in the years to come we will look upon the agreement signed today as a monument to the ways of peace, standing in sharp and profound relief upon a desolate plain of war and destruction."1

To consider the trade agreements program as simply a matter of reducing some of the rates in our tariff and of obtaining lower rates abroad for some of our exports is to fail to appreciate the true character of this most important work. What gives to the agreements their significance is that they are the central feature of the whole body of policies which the United States Government has been applying for the past

* Formerly Member, Financial Section, Secretariat of the League of Nations, Geneva; Member, Central Banking Department, Bank for International Settlements, Basle; Chief Investigator, Office of the Special Adviser to the President on Foreign Trade; Assistant Chief, Division of Trade Agreements, Department of State; Foreign Exchange Manager, General Motors Overseas Operations. At present, President of The Eastern Housing Corporation and other companies.

${ }^{1}$ N. Y. Times, Oct. I5, I941, p. 7. 
eight years to one of the most important parts of our foreign relations, that of international commerce. These policies are based on two great principles of government.

The first principle is that men prosper best under a liberal order, a principle which is nowhere more true than in the field of international commerce. The second is that established rules as opposed to expediency must guide and govern action. These twin principles of liberalism and law have been applied steadfastly by the United States to its international commercial policy at a time when autarchy and anarchy were spreading throughout the world with a rapidity and a vitality which threatened to engulf the trade of all nations. Thus the United States Government, through its commercial policy and particularly through the trade agreements, has erected a standard to which all those can repair who recognize that the restoration of an orderly world where democratic processes can continue to be enjoyed, depends on the reassertion of liberal methods of government and on a renewed willingness of governments to govern and of peoples to be governed by impartial laws founded on principles having general acceptance.

Circumstances similar to those of the present have prevailed in the world before. It is interesting to look backward and note where our present government's commercial policy fits into the broad flow of history.

It was not until the nineteenth century, following the defeat of Napoleon and the reorganization of Europe at the Congress of Vienna, that conditions favorable for expanding trade between nations were created. At that time the world was confronted with a situation not unlike the present: order throughout Europe had been destroyed, confusion was widespread, and it was difficult to see how or where reconstruction could be begun. The reconstruction which was in fact brought out of that chaos owed its success to the fact that it was based on liberalism and on law, avoiding opportunism and expediency.

The era was one in which liberal methods and the rule of law were uppermost in men's minds throughout the western world. The French and American Revolutions, the writing of our Constitution, the reorganization of Europe at Vienna, the confederation of Switzerland under a constitution, and the birth of various republics in Latin America set the framework for the century of unprecedented growth and prosperity which preceded the First World War.

In the sphere of international commerce liberal ideas made themselves felt, primarily through British initiative, in generally moderate import restrictions. Attachment to principle and the desire to bring human relations under the rule of law had their effect in the development and widespread acceptance of the most-favored-nation policy. The existence of order in international trade has been brought about more through this very important policy than through any other means. A description of its operation will be given later. Suffice it here to say that the great expansion of world commerce in the past century could not have taken place in its absence.

Between $I 850$ and $19 I_{4}$ the value and volume of international trade were multiplied almost five times. The world's output of goods and services increased at an 
average annual rate of about three per cent compared with an average increase of less than one per cent in the world's population, leaving a substantial margin for a steady improvement in the standard of living. In some countries real wages were trebled between $185^{\circ}$ and I9I4. This long period of advance had its basis, financially, in a common monetary standard (the international gold standard) and in an increasing volume of international lending, and, commercially, in relative freedom of trade conducted under accepted principles and established laws.

The delicate organization on which the prosperity of the nineteenth century rested was destroyed by the First World War. The war disrupted relationships between producers and markets. In the newer countries such as Canada, Australia and Argentina, the productive facilities for agricultural goods were enormously increased and industrialization was begun. In the United States the Great Plains were ploughed and sowed to wheat, and the capacity of our industrial plant was greatly expanded. When Europe after the war returned to its normal tasks, there resulted a world whose productive facilities far outstripped the purchasing power it possessed in its economically unbalanced condition. In these circumstances sound economic reconstruction required that the commercial policies of the world's chief trading nations should be directed at holding barriers to commerce as low as possible in order that the maximum exchange of goods could take place.

Unfortunately, just the opposite course was followed, in no small measure because of the policies adopted by the United States. The United States had emerged from the war the most important country politically and economically so that the course which it chose to follow had the greatest influence upon the development of world policy. But this country was then in a phase of strong isolation which in the commercial sphere found expression in the Emergency Tariff of rgar shortly followed by the sweeping upward revision of the Fordney-McCumber Act of 1922.

Other nations were not slow in adopting similar policies, some wishing to make themselves self-sufficient, some because of economic pressure, but all in varying degree being influenced by our example, with the result that trade barriers throughout the world grew higher. Thus, instead of larger channels of trade being created to absorb the increased production that the new producing areas and the technological advances made possible, channels were gradually blocked and uneconomic production was widely fostered, laying the basis for the problems of surpluses that were to plague almost all nations in the succeeding years.

The World Economic Conference of 1927 , the greatest economic gathering of the reconstruction decade, saw clearly the danger of this trend and called upon governments to alter their policies. Unofficial representatives from the United States attended the conference and agreed in its recommendations, but in the very next year a presidential campaign took place in this country in which one of the candidates made an increase in our already high agricultural tariffs a principal plank in his platform. In I929 and I930 the Smoot-Hawley Tariff was written.

Not only did our policy of excessive import restriction reduce the ability of peoples 
to sell what they produced; it also created a most serious problem in international payment. The war had changed the United States from a debtor to the world's outstanding creditor nation, to which was due annually large sums on account of debt service in addition to payment for exports. Since we limited excessively the amount of goods that we would take, foreign lending and imports of gold were swelled to unsound proportions in order to settle our international accounts, each laying up difficulties for the future.

In pursuing these policies the government of this country was greatly at fault. Protection of domestic agriculture and industry is necessary, but the protection practiced by the United States. through the 'twenties was one which knew almost no bounds. Rates through one schedule after another were raised in many cases to practically prohibitive levels. The attitude was one of outright mercantilism, for while imports were restricted exports were forced by many methods. An indication of the trend of thought is provided by the Bureau of Foreign and Domestic Commerce which was most diligent and active in seeking out export opportunities for American goods but was not equipped or authorized until r935 even to provide information on import possibilities.

The United States, of course, bears only a share of the blame for the mistaken course followed but there is much to support the conviction that had we pursued a liberal commercial policy instead of a policy of forcing exports and restricting imports the history of the past twenty years might have been quite different. When the war ended the world faced a choice of roads and could for a brief period have been started on the course of liberal commercial policies and economic integration almost as easily as on that of restrictive policies and economic nationalism. It was the United States which gave the initial and most forceful lead toward the latter course.

As the depression came and deepened between I929 and 1932 trade barriers were rapidly increased, exchange restrictions, quotas and other import and financial controls being added to tariffs. The totalitarian governments then being set up seized avidly on the opportunity so afforded to undertake political pressures through the exercise of this form of commercial policy.

They substituted coercion for negotiation-“persuaded," with a blackjack. The countries thus victimized were forced to spend the proceeds of their exports in the countries where such proceeds were blocked, no matter how inferior the quality, how high the price, or even what the nature might be of the goods which they were thus forced to obtain. They were prevented by such arrangements from entering into beneficial trade agreements with countries unwilling to sanction discriminations against their exports. By no means the least of the victims were the exporters of third countries, including the United States, who were either shut out of foreign markets entirely or else only permitted to participate on unequal terms.

Our own export trade, no longer supported by foreign lending on the part of American investors, and unprotected against countless new trade barriers and dis- 
criminations, was immediately and disastrously affected. Our foreign commerce suffered more severely than did that of almost any other nation, our exports being reduced from $\$ 5.2$ billion in 1929 to only $\$ \mathrm{x} .6$ billion in 1932 . The effects on our domestic economy were so serious that the new administration was obliged to take some energetic action which, largely because of the appointment of Mr. Hull as Secretary of State, was developed along liberal lines. The enactment in 1934 of the Trade Agreements Act represented a new deal for our foreign trade.

\section{Legislative and Constitutional Bases of the Program}

The trade agreements program is based upon the Act of June r2, I934, popularly known as the "Trade Agreements Act." 2 The authority conferred by this Act was for three years. The Act has since been extended on two occasions for additional three-year periods from June $12,19377^{3}$ and from June $12,1940 .{ }^{4}$

The Trade Agreements Act was passed "for the purpose of expanding foreign markets for the products of the United States, as a means of assisting in the present emergency in restoring the American standard of living, in overcoming domestic unemployment and the present economic depression, in increasing the purchasing power of the American public, and in establishing and maintaining a better relationship among various branches of American agriculture, industry, mining and commerce." 5

For the accomplishment of this purpose the Act does three things. It authorizes the President to enter into trade agreements with foreign governments; it authorizes him in connection with these agreements to modify existing United States duties within a limit of $50 \%$; and it directs him to apply the modified duties to the trade of all countries not discriminating against the trade of the United States. In addition the Act contains several other provisions, among which may be mentioned those requiring interdepartmental consultation and the giving of public notice in order that private persons may have an opportunity to present their views.

The trade agreements method was adopted in preference to our historic practice of unilateral tariff adjustment because under it (i) we obtain something in return for our duty reductions in the form of an immediate liberalization in the import restrictions of the other country, (ii) we possess an effective weapon for combating foreign discriminations, and (iii) it is possible to proceed with a program of tariff adjustment and trade expansion in a gradual manner permitting ample time for study of all aspects of the innumerable problems involved.

The mechanics of the trade agreements program are not new. Each of the three main provisions of the Trade Agreements Act continued or rested on previous experience: the authority to enter into trade agreements had been granted to the President by the Tariff Acts of 1890 and 1897 , the authority to modify our import duties within a $50 \%$ range had been granted to him in our tariffs of 1922 and 1930 ,

${ }^{2} 48$ STAT. 943 , x9 U. S. C. $\$ \$ 3551-1354$.

454 Stat. 107, x9 U. S. C. A. \$1352(c) (Supp. 1940).

${ }^{3}$ 50 STAT. 24 (1937), 19 U. S. C. A. $\$ 1352$ (c).

54 STAT. 943, I9 U. S. C. \$135I(a). 
and the unconditional most-favored-nation policy which was written into the Act had been inaugurated by Secretary of State Hughes in 1923. All of these precedents without exception, it is interesting to note, were created under Republican Administrations.

The spirit underlying the trade agreements policy, however, is very different from that which underlay the commercial policy of the preceding administrations. Whereas our policy from I920-1934 was one of trade restriction, imposed and increased all too easily at the behest of domestic producers, the objectives of the trade agreements have been to reduce barriers to trade and remove discriminations in order to expand foreign markets for our products.

During the early years of the trade agreements program its opponents made several attempts, none of which progressed further than the lower courts, to attack the constitutionality of the Act.

One objection raised was that the Act violated the constitutional requirement that treaties must receive the consent of the Senate with two thirds of the Senators present concurring. Few lawyers, however, have agreed with this view. From its earliest days the United States has entered into numerous international agreements, as distinguished from treaties, in the fields of commercial and consular relations, patent, trademark and copyright protection, postal, navigation, radio and aviation arrangements, and the settlement of claims.

Two instances of legislation under which commercial agreements in the field of tariff duties were executed have come before the Supreme Court. Field v. Clark involved Section 3 of the Tariff Act of I8go which authorized the President to impose stated duties on named articles when imported from countries whose duties were reciprocally unequal and unreasonable. Some ten agreements were entered into without Senate ratification under this authority, three of which had been concluded at the time of the argument of Field v. Clark. The Act was challenged, in the language of the Supreme Court, "As delegating to him [the President] both legislative and treaty-making powers." After holding that the Act did not constitute an improper delegation of legislative power, the Court went on to say: ${ }^{8}$

What has been said is equally applicable to the objection that the third section of the Act invests the President with treaty-making power.

The case of Altman Company v. United States ${ }^{9}$ involved a commercial agreement under Section 3 of the Tariff Act of 1897 which expressly authorized the President without the necessity of Senatorial ratification "to enter into negotiations" with countries exporting named articles to the United States, "with a view to the arrangement of commercial agreements in which reciprocal and equivalent concessions may be secured in favor of the products and manufactures of the United States" in return for our substitution of lower duties on the named articles in place of existing duties. The Supreme Court described the commercial agreement with France negotiated

i I43 U. S. 649 (I892).

${ }^{8}$ Id. at 694 .
${ }^{7} I d$. at $68 \mathrm{r}$.

${ }^{9} 224$ U. S. 583 (I912). 
under this provision as "an international compact" although "not a treaty possessing the dignity of one requiring ratification by the Senate."10

In the more recent decision of Monaco v. Mississippi, ${ }^{11}$ Chief Justice Hughes, speaking for the Court, stated that the Federal Government may effect international settlements "through treaty, agreement of arbitration, or otherwise." ${ }^{12}$ Finally, in the 1936 case of United States v. Curtiss-Wright Export Corporation, ${ }^{13}$ the Supreme Court expressly stated that the Federal Government has "the power to make such international agreements as do not constitute treaties in the constitutional sense." This and related powers the Court found to be "inherently inseparable from the conception of nationality" and essential to make the United States "completely sovereign."

The only other important constitutional objection leveled at the Trade Agreements Act is that insofar as the Act provides for modification of domestic duties it involves an unconstitutional delegation of legislative power. The decision of the Supreme Court just mentioned, in the Curtiss-Wright case, definitely established that, in providing for the carrying out of legislation affecting the foreign relations of the United States, Congress may vest in the President far greater discretion than would be permissible in the case of enactments which relate solely to domestic matters. The Court recognized that Congressional legislation which, like the present Act, "is to be made effective through negotiation and inquiry within the international field must often accord to the President a degree of discretion and freedom from statutory restriction which would not be admissible were domestic affairs alone involved." After reviewing a long list of statutes authorizing action by the President with respect to our foreign relations, many of which are characterized in the opinion as leaving "the exercise of the power to his unrestricted judgment," the Court stated ${ }^{14}$ that:

The uniform, long-continued and undisputed legislative practice just disclosed rests upon an admissible view of the Constitution which, even if the practice found far less support in principle than we think it does, we should not feel at liberty at this late day to disturb.

This decision seems to leave little room for doubt as to the constitutionality of the Trade Agreements Act. Indeed, that Act is so framed that it meets the more rigorous tests laid down by the Supreme Court for determining the constitutionality of legislative delegations of power in the purely domestic field. The legislative policy is clearly stated, a definite course of procedure is to be followed, adequately defined standards for the President's guidance in executing that policy are established, and a finding of fact is required as a condition precedent to action by the Executive. ${ }^{15}$

${ }^{10} \mathrm{Id}$. at $60 \mathrm{x}$.

${ }^{11} 292$ U. S. 313 (1934).

18299 U. S. 304 (1936).

${ }^{12}$ Id. at $33 \mathrm{I}$.

2" Id. at 329 .

${ }^{20}$ The most important recent statements and papers discussing the constitutionality of the trade agreements are the following: (I) Letter of March 4, I940, from Robert H. Jackson, then Attorney General, to the Secretary of State, enclosing a memorandum, prepared in the Department of Justice, on the "Constitutionality of the Trade Agreements Act," printed in Hearings before the Senate Committee on 


\section{Procedures Developed for the Administration of the Program}

The administration of the trade agreements program presents a strong contrast to the methods frequently exhibited by government. Instead of a new and large organization being set up, as is so often done to administer a new act, the existing facilities of the government were utilized and relatively few new jobs were created. As a result the cost of the program since the start has been kept without particular difficulty or hardship within a very small figure.

The trade agreements represent the cooperative effort of all of the government organizations having direct connection with foreign trade which means, in addition to the Department of State, principally the Tariff Commission, the Department of Commerce, the Department of Agriculture and the Treasury Department. The work has been conducted very largely through the medium of committees, the most important being the Trade Agreements Committee. This committee has sub-committees of three classes, some dealing with countries, some with commodities and some with special technical problems, and all composed of experts drawn from the several departments. When the program was in its most active period, in 1937, these subcommittees numbered more than sixty.

The procedure for the preparation of an agreement is approximately as follows. When the negotiation of a trade agreement is under consideration a committee on the country concerned is created. This committee investigates with painstaking thoroughness the products which make up our exports to that country and our imports from it, working on material prepared for the most part in the Tariff Commission and the Department of Commerce. When commodities whose situation is particularly complex are encountered they are frequently referred to the commodity committees. The task of the country committee, assisted by the commodity and special committees, is to prepare recommendations as to the various concessions which we should endeavor to obtain from the other country and those which it would be possible to give in return. Many months of concentrated work are often required before these recommendations can be completed. They are then reviewed with care by the Trade Agreements Committee after which they go to the Secretary of State, and possibly to members of the Cabinet and to the President, for approval. In the negotiations which follow, the concessions which our negotiators will actually offer to the other country will, of course, not always be the maximum authorized but will depend upon the degree to which our requests are met. When the negotiations are completed the draft agreement goes to the Secretary of State and to the President for final approval.

During the course of the preparation of an agreement the public is given the opportunity to participate at several points. At a relatively early stage a public an-

Finance on H. J. Res. 407, 76th Cong., 3d Sess. (1940) 728-743 (These hearings related to the extension of the Trade Agreements Act in 1940.); (2) Statement of Green H. Hackworth, Legal Adviser of the Department of State, Hearings before the House Committee on Ways and Means on H. I. Res. 407, 76th Cong., 3d Sess. (1940) 2480-2493; (3) Francis B. Sayre, The Constitutionality of the Trade Agreements Act (1939) 39 CoL. L. Rev. 75I; (4) The Trade Agreements Act of 1934 (1937) 46 Yale L. J. 647. 
nouncement is made that a trade agreement is contemplated, and the public is invited to submit suggestions as to the products which should be included in the negotiations, either imports or exports. At a later step formal notice of intention to negotiate is given, as is required by the Trade Agreements Act, and a period is fixed during which formal written statements may be filed. A list is published with this second notice naming the products to which we will limit ourselves in granting concessions to the other country, in order that persons interested in products which will not be considered may be spared the trouble of submitting statements. Finally, after the close of this period there is held a public hearing.

No method of tariff making could be more democratic than this for everyone has full opportunity to present his case and everyone is given equal consideration. Lobbyists, who did such a profitable business in the days when tariff schedules were framed in committees of the House and Senate, are out of the picture. Their employment under the trade agreements procedure is not only unnecessary but may even tend to discredit the case they are engaged to represent.

In another respect also the trade agreements procedure represents a long step forward from the method of tariff adjustment formerly employed in this country. Until I934 it was customary for our entire tariff, with its thousands of classifications and rates, to be given a general overhauling every few years, such periodic revisions usually coinciding with the advent of a new administration and reflecting domestic political considerations more than the needs of our economy or of our foreign trade. In the intervals between these revisions nothing was or could be done until the inclusion of the so-called "flexible tariff provisions" in the Tariff Acts of 1922 and I930, and the use made of these provisions was simply a mockery of the purposes proclaimed when they were written. ${ }^{16}$ In contrast to this older method, the trade agreements provide a procedure under which our import restrictions are kept subject to continuous review. We are now, as practically all other nations have been for years, able to move on short notice either to defend ourselves commercially at this or that point or to take advantage of opportunities. While providing these great advantages the trade agreements have, paradoxically, made tariff adjustments less unsettling to business and the protected domestic industries than was the old method, for changes in rates are now made on specific lists of products, within known limits, on the basis of clearly defined policies, and following an established procedure. Formerly, when the tariff was opened for revision in Congress, regardless of the original intention a free-for-all developed under which each interest got what it could.

The suggestion has at times been made that the conduct of our commercial policy and of the trade agreements should be confided to some special foreign trade agency to be created. The present arrangement under which a number of government departments and agencies work in close cooperation, each bringing its specialized knowledge and viewpoint, has proven both effective and inexpensive. The creation

\footnotetext{
${ }^{10}$ A very good detailed study of the operation of the flexible tariff provisions is found in a small book by John Day Larkin, "The President's Control of the Tariff," published in 1936 by the Harvard University Press as one of the Harvard Political Studies.
} 
of a new organization such as a foreign trade board would constitute simply an unnecessary increase in our present overlarge bureaucracy. Moreover, such an organization, or the Tariff Commission if the executive work on foreign trade were confided to it, would gradually come to deal with foreign trade matters as largely domestic problems. Any organization, be it an old one or one newly created, would tend, if entrusted alone with the administration of our foreign commercial policy, to develop and emphasize some special viewpoint. The strongest feature of the present cooperative arrangement is that it makes one-sided administration of any sort practically impossible.

\section{The Unconditional Most-Favored-Nation Policy}

Of the various aspects of the trade agreements none compares in importance with the unconditional most-favored-nation policy. While that policy has had many unfriendly critics the interesting thing to be noted about them is that in six years they have been able to make so little of their case. The reason for this is that when the policy is closely studied one is forced to the conclusion that it has no practical alternative.

The unconditional most-favored-nation policy is the policy of equality of treatment; the only alternative to it is the policy of discrimination, one which in the long run is disadvantageous for any nation and would have been particularly so for us who have normally had an export surplus in our trade with the great majority of countries. If we did not treat other nations equally in our market, but instead gave preferences to some and discriminated correspondingly against others, we would have to expect that our exports would be treated in the same manner. The negotiation of trade agreements would then become a matter of exclusive bilateral bargaining, which means nothing more or less than fighting all over the world for scraps of trade on a tooth and claw basis.

Under the unconditional most-favored-nation policy the United States has extended the concessions which it has granted in trade agreements unconditionally to all other countries provided that they followed a like policy toward us. ${ }^{17}$ In effect this has meant that we have given non-discriminatory treatment to other countries in return for non-discriminatory treatment of our trade by them.

The criticism has been made that under this policy we give away something for nothing. Nothing could be less true. When we reduce one of our duties in a trade agreement the other country "pays" us for this concession. That country, in almost all instances, is the chief supplier of the product in question and, therefore, the

\footnotetext{
${ }^{27}$ The unconditional most-favored-nation policy, in so far as it is embodied in contractual obligations, operates in the same manner in other countries as in the United States. Other countries, parties to the trade agreements, however, may or may not extend to third countries with which they do not have mostfavored-nation contractual obligations the concessions which they grant to the United States. They are not obliged by the terms of trade agreements with us to extend to third countries their concessions to us, for this is, after all, a matter of their own policy which concerns us only remotely if at all. It is believed that in the main they have done so with respect to tariff concessions although to a lesser extent with concessions covering exchange and quantitative controls.
} 
country most willing to "pay" us to reduce our duty on it. Now there may be one or two, or maybe a dozen, secondary suppliers. If we do not give the lower rate to them at once, but instead levy the old rate on their goods and try to get them to pay us with some direct concession for the lower rate, they will find that their business is discriminated against in the meantime. They will retaliate, will impose some fresh handicaps on our exports, and we will find when the smoke has cleared away that we are right back to where we would have been had we extended our lower rates to them in the first place.

By having extended our trade agreement rates immediately to all countries not discriminating against us, which "cost" us very little if measured by the extent to which it increased our imports, we received many benefits. In countries having two or more tariff rates we received with but few exceptions the lowest rates enjoyed by any foreign nation; in all countries we received the reduced rates that were given in agreements with other foreign countries or which were fixed autonomously; and in countries having exchange controls, quotas, import licenses, government monopolies, etc., we received treatment which, in the light of the existing circumstances, was as favorable as that granted to other nations. All these advantages we obtained immediately, unconditionally, and without having to bargain for them. The policy of equality of treatment, the unconditional most-favored-nation policy, has been the cornerstone of the trade agreements program. Without it, that program would have been a danger rather than an aid to our foreign trade.

It is in this matter of equality of treatment that the fundamental cleavage is found between the commercial policies of the totalitarian states and those of the democracies. The commercial relations built up by Germany, for instance, are a tangled and intricate webb of preferences, discriminations, unfair trade practices, and strongarm methods, all employed to secure some immediate German interest, with little thought to the future and with callous disregard of the damaging effect of these actions on others. The democratic states have not held themselves entirely free from some of these same methods. Even Great Britain, while not entering into strictly bilateral arrangements, incorporated bilateral features in many of its agreements. The important fact that stands out, however, is that the democratic states, to the extent that they adopted these methods, did so mainly in self-defense and in the pressure of circumstances which they did not create. The main struggle on the commercial front between the totalitarian states, led by Germany, and the democracies, led by the United States, has been fought over the principle of equality of treatment.

In each of the trade agreements into which the United States has entered with the countries of Central and South America and the Caribbean, reciprocal equality of treatment has been assured, with the exception of Cuba whose commercial relations with us have been on a preferential basis since I902. In some of the earlier agreements, such as that with Brazil, the assurances were of a general character, but in all the later agreements, negotiated after we had developed our technique of dealing with this problem, the most explicit and detailed guarantees are exchanged. 
The obtaining of these guarantees, in satisfactory form and scope, has been the most difficult problem confronting our government throughout the life of the trade agreements program. Particularly has this been the case with the countries of Latin America which, being in the main agricultural and raw-material producing states, have been vulnerable to pressure from Germany, Italy and other countries. The fact that satisfactory guarantees have been obtained from all of the Latin American countries with which we have trade agreements is an evidence of the strength of this country and a credit to the patience and skill of its negotiators.

Only in the case of the trade agreement signed last October $14^{\text {th }}$ did the United States recognize special exceptions to the general assurance of unconditional mostfavored-nation treatment. Two special exceptions are dealt with in two exchanges of notes, one of which provides in substance that during the present emergency and so long as the proceeds of Argentine exports to the United Kingdom are blocked by that country, the Government of the United States will not invoke the most-favorednation provisions of the agreement in respect to Argentine exchange or quota treatment of imports from the sterling area; and the other of which relates to Argentina's special trade relations with contiguous countries and Peru.

The importance of Argentina politically and economically, and the urgency of reaching agreement after the years through which conversations and negotiations had been protracted, doubtless justifies the acquiescence of our government in these two exceptions. Their effect commercially will not be important; the exception regarding exchange simply gives formal recognition to a situation which had existed for some time; and that concerning contiguous countries and Peru can create little additional competition against our exports to Argentina. From the viewpoint of policy it may be regretted that the exceptions had to be made, but the special circumstances underlying their acceptance are so strong that they cannot be considered as representing significant departures by the United States from its established principles. Moreover, the more objectionable exception, from a policy viewpoint, that admitting regional preferences, it is provided shall cease at the end of the war. The justification of the regional preferences in the Danubian states which were recognized by the United States in the trade agreement with Czechoslovakia is lacking in the case of Argentina, if not in that of all Latin American countries.

The insistence by the United States of equality of treatment throughout Latin America, and the inclusion of unconditional most-favored-nation assurances in the trade agreements with all Latin American countries except Cuba, has opposed the most comprehensive and effective barrier to German and Italian commercial penetration in this hemisphere. More than the specific commodity concessions obtained, the most-favored-nation guarantees have operated at once to defend our own exports and to restrict the use of the trading practices which Germany and Italy employed with such devastating effect in Central and Eastern Europe. 


\section{Accomplishments of the Program}

Under the Trade Agreements Act the United States has concluded agreements with 22 foreign countries. These countries, in the order in which the agreements were signed, are: Cuba, Belgium, Haiti, Sweden, Brazil, Canada, the Netherlands, Switzerland, Honduras, Colombia, France and colonies, Guatemala, Nicaragua, Finland, El Salvador, Costa Rica, Czechoslovakia, Ecuador, the United Kingdom including Newfoundland and the British Colonial Empire, Turkey, Venezuela, and Argentina. ${ }^{18}$ A second agreement with Canada, which entered into effect January I, I939, replaced the first agreement with that country, which had been in effect since January I, I936. In addition, a supplementary trade agreement has been negotiated with Canada and another with Cuba.

Lowered tariff rates, more liberal quotas or exchange restrictions, and assurances against adverse changes have been obtained with regard to hundreds of American products, both agricultural and non-agricultural, comprising more than one third of all United States exports.

In return the United States has agreed to tariff reductions or to the "binding" of existing tariffs or free entry in the case of imported products needed or desired by American industry or American consumers. Concessions on imported commodities similar to those produced in the United States have been granted by this country only after particularly exhaustive study indicates that such concessions can be made in the national interest without serious injury to the American producers concerned. When it appears necessary, tariff modifications on such products are limited by quotas which set upper limits on the imports permitted to enter at the reduced tariff rates, or by restriction of tariff reductions to seasons when competing American products are not marketed in quantities sufficient to satisfy the demand.

Since the outbreak of the war our foreign trade has been so changed that any statistical appraisal of the results of the trade agreements must refer to the period preceding September, I939. While many other factors besides the trade agreements influenced both the volume and nature of our trade even in the pre-war period, an examination shows that the agreements contributed in a significant degree to increases in our foreign commerce during the five years from 1934 to 1939 .

During the 2-year period 1934-35, United States total foreign trade averaged $\$ 4 . \mathrm{r}$ billion a year. In the 2-year period $1938-39$, the average was $\$ 5.3$ billion. In the 2-year period 1938-39, when there were 16 trade agreements in effect throughout the entire period, United States exports to the countries covered by these agreements averaged

${ }^{18}$ Treaties with Latin American nations were signed and became effective on the dates set forth below:

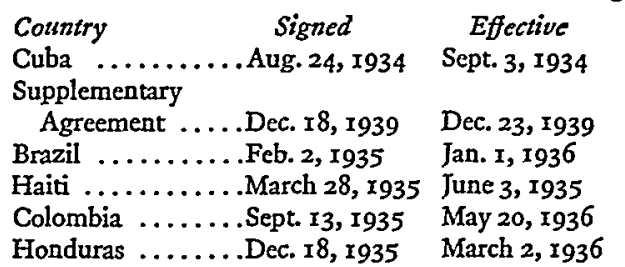

Country Signed Effective Nicaragua ........March $\mathrm{rr}, \mathrm{1936}$ Oct. $\mathrm{x}, \mathrm{1936}$

Guatemala ....... April 24, 1936 June 15,1936

Costa Rica ........Nov. 28, 1936 Aug. 2, 1937

El Salvador .......Feb. 19, 1937 May 31, 1937

Ecuador .........Aug. 6, r938 Oct. 23,1938

Venezuela ........Nov. 6, 1939 May 5, 1939

Argentina ......... Oct. 14 , x94I Nov. 15, x941 
$62.8 \%$ greater than in $1934-35$, when only one agreement was in force for a year or more, while our exports to all other countries increased by $3 \mathrm{r} .2 \%$. In addition to the 16 agreements in effect throughout $1938-39$, two agreements, with the United Kingdom and with Ecuador, were in effect throughout all of r939. Our exports to these 18 countries with which agreements were in effect throughout 1939 averaged $50.5 \%$ gxeater in $1938-39$ than in $1934-35$, while our exports to all other countries increased by only $31.7 \%$.

Our imports from the 16 agreement countries averaged $21.6 \%$ greater in $1938-39$ than in 1934-35, while our imports from other countries averaged II.I\% greater. Our imports from the countries covered by the $\mathrm{I} 8$ agreements increased by $17.8 \%$ and from all other countries by $12.5 \%$ during the same period.

As these statistical comparisons are wearying they will not be multiplied, but there are others of a different nature which point to the same answer. ${ }^{19}$ They reinforce the common-sense conclusion that the reduction of excessive tariffs and other barriers to the exchange of goods makes possible increased trade to the benefit of all concerned.

The United States is the greatest producing nation. It can in time of peace put a vast number of agricultural and industrial products on world markets at prices which are highly competitive. Americans not engaged in foreign trade frequently do not realize how great the world demand for our goods is. All over the world people who have the purchasing power to do so want to buy American goods, for they are attractive, progressive, of good quality, and are reasonably priced. But with our tariff we proceeded to shut out of our country the goods which these people produce and so their governments had little choice but to place restrictions on our goods. A nation must keep its accounts in balance just as must an individual. It cannot for long buy more than it can sell, for if it does in the end it will face bankruptcy. A nation must sell if it is to be able to buy, and a nation which wishes to sell must also be willing to buy.

Particularly has this been true of a nation like ourselves which in addition to selling goods wished to collect from abroad large amounts of interest and dividends. Through the years following the First World War we were in this position, yet our tariff policy continued to be that of a debtor nation. And so high tariffs, exchange restrictions and quotas kept our goods out of foreign countries. The severity of these restrictions is evidence of the strength of the popular demand for our products that foreign governments felt they had to curb. In measuring the effects of the trade agreements, account should be taken of the improved balance which they have tended to establish between ourselves and the rest of the world.

${ }^{10}$ Such statistical information has been presented in many places. The following three references may be mentioned as among the most comprehensive: (I) Testimony of Mr. Henry F. Grady, Hearings before Senate Committee on Finance on H. I. Res. 407, 76th Cong., 3d Sess. (1940) 105-130; (2) Status of Trade Agreements Program, U. S. Dep't of State, April 25, 1940 (mimeo.); (3) Economic Studies of the Effects of Trade Agreements Upon American Agriculture (Report prepared for the American Farm Bureau Federation, Chicago, Ill., by T. W. Schultz, C. J. Shohan, and A. Erickson, Iowa) in Hearings before the House Committee on Ways and Means on H. J. Res. 407, 76th Cong., 3d Sess. (1940) 17221837. 
There are other beneficial effects of the trade agreements of a more general character which should not be overlooked.

Tariff protection, apart from its revenue-raising aspect which has become unimportant, is intended to support industries which for one reason or another are unable to support themselves. It may be desirable to do this to get new industries started, and it may be desirable, for national defense or other purposes, to continue to protect some industries indefinitely after they have grown up. But it must be recognized that the more industries of this nature that a nation does maintain, the weaker is its economic structure. Such industries, despite their protection, are continually sensitive to foreign competition. Depression affects them sooner and they recuperate more slowly. It is those industries which stand on their own feet, and which lean as little as possible on the government, that are the strongest and most desirable in the national economy.

It is also to be noted that tariff protection has for long been one of the most potent factors in creating price rigidity, a disease as fatal to capitalism as hardening of the arteries is to man. A moderate tariff policy permits the people of that country to participate in the benefits flowing from technological or other advances in production occurring in any part of the world.

General advantages such as those mentioned in the preceding paragraphs, of course, flow from a moderate import policy regardless of how that policy is made effective. In the trade agreements a successful method has been found to carry out a liberal commercial policy. The general and broad advantages of such a policy, as well as the immediate trade gains, must therefore be placed in the balance in appraising the effects of the trade agreements.

\section{Problems and Attempted Solutions}

At the beginning of the last decade the economies of the American republics were, generally speaking, in a relatively prosperous condition although the first rumblings were audible of the troubled days ahead. Foreign trade, at that time as now, one of the most obvious barometers of general conditions, was at a high level, supported by high prices and a relative freedom of movement. The effect of foreign borrowing, although beginning to taper off, was still sufficient to permit international payments to be balanced and currencies to remain fairly stable.

By the middle of 1930 , however, appeared the first marked signs of the depression as raw-material price declines gained momentum. Falling more rapidly and to considerably lower levels than prices of finished goods and semi-manufactures, world prices for such important Latin American export commodities as copper, wheat, coffee, sugar and tin had declined by the end of 1932 to hardly more than $40 \%$ of the levels at the beginning of 1928 . The price index for finished goods and semimanufactures in the United States, on the other hand, declined during that period only to $73 \%$ and $62 \%$, respectively, of the 1928 levels. The effect on Latin American foreign trade, of course, and in turn on the internal economy, was rapid and severe. 
Chilean foreign trade, hardest hit, had by 1932 declined to but $13 \%$ of its value in 1929. The practical cessation of foreign investments aggravated the difficulties resulting from the shrinking value of exports. Government revenues, dependent to an important extent upon customs duties, declined rapidly and resulted not only in internal difficulties but also in suspension of foreign debt service in various countries. Gold stocks were depleted and currency depreciation set in. All but a few elements of the national economies were caught in the descending spiral.

Practically all of the Latin American governments were faced early in the depression with the necessity of adopting drastic measures to meet these rapidly changing situations. Since the causes of the difficulties resulted primarily from the deterioration of economic relationships with the rest of the world, it was natural that the first defensive measures should involve readjustments in those relations. Thus, controls were established which, although varying in their details and manner of application from one country to another, were designed to restrict imports within reduced exchange availabilities and secondly to control those availabilities in a manner which would permit their most efficient use from the point of view of what seemed to be the national interest.

These were in the first instance the primary objectives of increases in tariff rates and the operation of exchange control. Increased import duties were directed in a large part against articles regarded as luxuries and, in the case of exchange control, exchange for payments of such articles and for non-commercial purposes was subject to long delays or was supplied only at unfavorable rates in order that exchange availabilities could be utilized primarily for essential imports.

Soon, however, the operation of exchange and trade controls became subject to pressure from foreign countries. The usual export surplus of Latin American countries presented certain European importing nations with an opportunity to accomplish two purposes: the liquidation of balances blocked in Latin American countries for lack of exchange, and the forcing of their own exports. Thus a large number of bilateral clearing or compensation agreements came into existence. This development presented to the United States Government one of its most difficult problems in inter-American economic relations.

Through the operation of clearing and compensation agreements many Latin American countries lost a large measure of control over the proceeds of their exports. One result of this development was that the supply of exchange available for payments to the United States was restricted, which either obliged the countries concerned to curtail imports from the United States or forced American exporters to accumulate funds blocked in the local currency. Another result was that purchases formerly made in the United States were switched to European suppliers which, through their control of the proceeds of Latin American exports, were able to force this diversion. Thus Latin America to an important degree lost control not only over its exchange availabilities but over the content and direction of its foreign trade 
as well. A factor aggravating this problem, of course, has been the unitary nature of Latin American exports.

The trade agreements program provided our government with two means of attacking this complex and difficult situation. In the first place it was felt that the United States could contribute in considerable measure to the easing of exchange difficulties in Latin America through the reduction of those trade barriers which have prevented a larger flow of imports from that area into this country and through the maintenance of those conditions under which goods moving freely might continue to be imported without restrictions. Since the initiation of the program in 1934 a major effort has been made to conclude trade agreements with the Latin American countries in which these results could be achieved. This effort has been largely successful. Of the 22 nations with which agreements have been made, twelve are in Latin America. Only eight of the American republics are missing from the list: Bolivia, Chile, Paraguay, Peru and Uruguay in South America; only Panama in Central America; only the Dominican Republic in the Caribbean; and Mexico.

In the second place through the bargaining power which the Trade Agreements Act placed in the hands of the government a constant struggle was waged against the encroachments in the Latin American markets of Germany, Italy and other powers employing bilateral and restrictive trading methods.

The most simple form of assistance thus given to our exports was through the reductions in the import duties of the agreement countries on our goods. Such duty reductions in many instances formed the quid pro quo for the reductions or bindings of import duties granted by the United States. Efforts to secure duty reductions, even though these concessions were distinctly secondary in importance in many cases to concessions applying to exchange and quantitative controls, were complicated throughout Latin America by the close relationship between foreign trade and governmental finances. Although considerable headway has been made in a few of the more economically advanced countries of Latin America during the last decade to broaden the tax base, it is still largely true that the most important single source of government revenue is customs duties.

In general the most valuable concessions for our exports, and correspondingly the most difficult to obtain, have been those affecting exchange control and quota systems. In some cases, notably that of Chile, success has not yet been had, for the nature of Chile's exports makes the country particularly subject to European pressures while providing the United States with unusually little bargaining power with which to counter those pressures. Nevertheless, if Latin America be viewed as a whole over the period from 1934 to 1940 , the conclusion is inescapable that the trade agreements program provided a very effective defense of our interests against these trade diversion and restrictive devices, and that it was unquestionably more effective than any other policy which was open to the United States to follow.

A large part of the government's defense of our export markets against the operation of controls other than tariffs was through the policy of reciprocal equality 
of treatment. It has been this country's practice, under the authority of the Trade Agreements Act, to withhold the extension of the trade agreement concessions and other favorable treatment from countries found to be discriminating in a substantial manner against United States trade. As the body of the trade agreement concessions assumed increasing importance the desire of other countries not to be excluded from these benefits became increasingly strong. Thus the policy of equality of treatment provided an effective means of defending our foreign trade both in the countries with which trade agreements were concluded or under negotiation and in other countries. In Latin America this means of economic defense assumed a particularly large role, for with many of the American republics the value in dollars and cents of the direct concessions in our duties which we could grant to them was small; hence our bargaining power was relatively weak other than through the policy of equality of treatment. Of course, the political aspect of not being excluded from the circle of countries receiving most-favored-nation status from the United States played a part as important as the commercial.

The technique generally employed for measuring equality of treatment under controls which deprive outside nations of unhindered equality of opportunity to compete has been that of the base period. A period is selected of one year, or three years or even more, which is considered by both parties to be representative of their normal commercial relations. Such a period will usually be one prior to the imposition of the controls in question. Both nations then give assurances that they will grant to the other, with respect to exchange or quantitative restrictions or whatever the controls may be, a share of the total amount of exchange, or of the total permitted imports, corresponding to the share enjoyed by that country in the base period. While this treatment cannot, within the strict meaning of the term, be considered unconditional most-favored-nation treatment in that it does not assure unlimited equality of opportunity, it is as close to completely fair and equitable treatment as can be achieved under exchange and quantitative controls.

The above are, in brief, the ways in which the United States, through the trade agreements and by means of the policies on which the trade agreements are based, has defended its commerce and sought to increase its markets in Latin America. They are not spectacular methods, nor are they the methods of those who like to wield the big stick. They are, however, fully in harmony with the principles and standards of democracy, and they are entirely consonant with the nature and aims of the Good Neighbor policy. Their effectiveness is given striking proof by the record of our trade with Latin America, and our share of the total trade of Latin America, both of which have increased with little interruption from I934 to the present time.

\section{The EFFEct of THE WAR}

From I934 to the outbreak of the war, the trade agreements program represented the major effort of the government in the field of foreign trade. Since the war started the policies embodied in the trade agreements have continued as the basis of 
our commercial policy, but other measures mainly of an emergency nature have come to occupy the center of the stage. What has happened to our trade during the war and what some of these other measures are, merit brief description as the setting in which the trade agreements operate today.

Significant changes have occurred in our foreign trade since the outbreak of the war. Both exports and imports have shown marked increases. The global figures, however, conceal important changes in the direction and composition of our foreign trade.

As regards exports the period has been one of steadily contracting markets in some parts of the world and steadily expanding ones in others. Virtually the entire continent of Europe west of the Soviet Union, as well as some parts of Africa and the Near East, is cut off by the British naval blockade. On the other hand there has been a great expansion of our exports to the United Kingdom, Canada, and other parts of the British Empire, as well as a substantial increase in sales to Latin America and the Far East.

Well over half of the increase in exports has been caused by rapidly mounting sales, and shipments under the lend-lease program, of finished manufactures, reflecting mainly the growing demand for aircraft and other implements of war. More than one third represented semi-manufactures. Crude materials have also shown a substantial rise. The largest single increase occurred in the exports of iron and steelmill products. On the other hand there has been a marked decline in our exports of tobacco and certain types of foodstuffs.

With our imports the exigencies of war have also played a decisive role. Blockade measures affect the exports of the blockaded countries as well as their imports. The British productive effort has been directed more and more toward war output. These factors have necessarily retarded our imports of finished manufactures. On the other hand, the expansion of our domestic industrial activity has been reflected in increased imports of raw materials, and particularly of certain strategic raw materials needed for defense.

The increased export surplus of the past ten years has been offset mainly by imports of gold. Although much of this gold has come from monetary reserves rather than from new production, the war has not so far produced disordered foreign exchanges. This has been so principally because of the existence of stringent exchange control in the United Kingdom and the other British countries and because of the virtual disappearance of trade between the continent of Europe and the rest of the world. On the other hand, the growing severity of exchange control, in the countries directly involved in the war as well as in many countries not directly involved, has had serious effects on our foreign trade. From the point of view of our policy in this field, the outstanding development has been the decision to place under license the funds belonging to nationals of the European countries which have been overrun.

One of the most interesting phenomena of the period is that our increased exports have been financed without recourse to new loans. Credits have been extended to several South American countries and some direct investment has taken place there. 
In the early stage of the war small loans were made to the Scandinavian countries. Some credits have also been furnished to China. The total amount, however, has been very small. Under the operation of the Johnson Act, no loans have been made to any of the principal belligerents. And under the Neutrality Act, purchases of war supplies have been on a cash basis. The creation of large international indebtedness is being avoided, of course, mainly because of the lend-lease program.

Broadly speaking, the foreign economic policy of the United States since the outbreak of the war has been directed toward two main objectives: First, to cushion the impact of war conditions on our domestic economy, so far as it is affected by international factors; and, second, to facilitate the program of national defense.

Our exports as a whole have been importantly affected by the Neutrality Act and the lend-lease program. The "cash-and-carry" provision of the former, adopted as a means of reducing the risks of this country's involvement in war, has had a retarding influence on our export trade. On the other hand, large shipments are now being made under the lend-lease program which, in the absence of that authority, would have been substantially smaller.

A striking feature of our export policy during the war period has been the adoption of a far-reaching system of export control as an element of the defense program. Since July, I940, powers have been vested in the President to place under license the exportation of various strategic and other essential commodities. The greater part of our exports of non-agricultural products are now subject to such licenses. This licensing system, together with the priorities regulations covering the allocation of a large part of our supplies and productive resources, has resulted in placing our export trade almost wholly under governmental control.

In this new pattern of things the trade agreements have necessarily played a secondary, if not minor, part. One extremely useful purpose they have served, however, has been in assisting the government to mitigate the severity of wartime trade controls imposed by other countries on our goods. While recognizing, of course, that decision as to the operation of such controls must necessarily rest with the belligerents imposing them, the government has sought, through formal and informal negotiations and with a substantial degree of success, so secure the application of these measures in a reasonable manner. In this respect the existence of trade agreements has been very helpful.

The outstanding government activity in the field of imports has been the purchase of various strategic and critical materials under the direction of the Army and Navy Munitions Board for the creation of stock-piles. Some of these purchases have been made from Latin America and have contributed to strengthening inter-American economic relations.

These relations have come, under the impact of war, to occupy a special place in the foreign economic policy of the United States. They are an important part of the Good Neighbor program for the Western Hemisphere, which is one of the foundation stones of the entire structure of this country's foreign policy and one of the essential features of the national defense effort. 
While the trade agreements provide the basic regulator of our commercial relations with Latin America various other measures in the economic field have been taken to meet the impact of war conditions. A general program of cooperative action was inaugurated in September, r939, at the first consultative meeting of Ministers of Foreign Affairs of the American Republics, held at Panama. At that meeting it was resolved that "in view of the present circumstances, . . . it is more desirable and necessary than ever to establish a close and sincere cooperation between the American republics in order that they may protect their economic and financial structures, maintain their fiscal equilibrium, safeguard the stability of their currencies, promote and expand their industries, intensify their agriculture, and develop their commerce."

To this end, it was decided "to create an Inter-American Financial and Economic Advisory Committee consisting of $2 \mathrm{I}$ experts in economic problems, one for each of the American republics." The Committee was duly constituted a few weeks later, and it has been meeting in Washington ever since.

As time went on and as the economic repercussions of war both in the present and in the future became intensified, the obvious need for more and more vigorous inter-American action led to a comprehensive review of the whole problem at the second meeting of the American Ministers of Foreign Affairs at Havana in July of last year.

From the Panama and Havana meetings and out of the work of the Advisory Committee a number of steps have resulted which can only be alluded to here. The Export-Import Bank has had the funds at its disposal very greatly increased not only to facilitate United States exports but "to assist in the development of the resources, the stabilization of the economies, and the orderly marketing of the products of the countries of the Western Hemisphere." Assistance has been given to several Latin American countries with respect to financial, monetary, and foreignexchange matters. The statute has been drawn up for an Inter-American Bank. An Inter-American Development Commission has been created as an agency for longrange economic development.

The foregoing is a very cursory survey of the effects of the war on our foreign trade and of the steps the government has taken, particularly with respect to Latin America. From a policy viewpoint it is a story of adaptation to conditions some of which are in large measure outside of our control, of effective utilization of available instruments of action in defense of the national interest, and of the forging of new tools to cope with new and extraordinary conditions. The basic principles of trade liberalization under the rule of equality of treatment, on which the trade agreements program is based, have remained the foundation of our commercial relations.

\section{Appraisal and Perspectives}

As was stated at the beginning of this paper, the great importance of the commercial policy followed by the United States during the past eight years, in particular the trade agreements program, is that it has represented a sustained attempt to 
regulate a most important branch of human relations on the basis of principle as opposed to expediency.

Even in the prosperous post-war decade the rule of principle in international commerce never achieved more than partial ascendancy over opportunism, and under the impact of the depression this was the first branch of foreign affairs to deteriorate into lawlessness. As early as $193^{\circ}$ catch-as-catch-can methods of conducting trade were rapidly displacing orderly processes in Central and Eastern Europe, and to a lesser extent in Latin America.

It was in foreign trade that the first irreconcilable differences occurred between the totalitarian states, notably Germany, and the democratic states, notably ourselves. Early in the day the totalitarian countries began to use foreign trade for whatever temporary advantage they could get out of it, commercially or politically, with little or no regard to the rights of others or to the long-term effects of their actions. In so doing they developed methods of conducting trade totally different from ours.

Under the totalitarian system foreign trade has come to be carried on virtually by government monopolies making use of subsidies, differential exchange rates, and barter agreements. It usually ignores costs, rests in many cases upon low-paid labor, and violates the rules of fair competition and international good will. The democratic type of foreign trade is carried on by private enterprise, without government interference except with respect to trade barriers. Orders go to that country and that enterprise which offer the best quality at the lowest cost.

The totalitarian states as a matter of policy adopted bilateralistic trading practices, often of the most extreme nature. They have treated each country with which they deal on an individual basis, forcing from it the maximum advantages for themselves without regard to its own welfare or to the rights of others. Thus, they have compelled other countries to buy from them as much as they buy from those countries, whether the other countries want their goods or not. In the main these acts have been openly opportunistic, without regard to settled commercial principles.

The totalitarian system bears also with severity upon its own citizens. The products which they may buy and sell in foreign trade are those that the government decides, as are the sources from which imports are obtained and the destinations to which exports are sold. Men are not free and do not operate under established laws, but rather as the government in each instance dictates; they are in fact little more than agents of the government. Such methods of conducting foreign trade do not fit into the pattern of our democratic life.

The existence side by side of the totalitarian and democratic systems, fundamentally and radically opposed one to the other, had the effect of dividing the world into two hostile groups, according to the character of the commercial policies and practices which they followed, with a third group of states, not complete masters of their own policies, caught in the middle.

By far the largest group, from the point of view of their total trade, was that of the democratic countries, principally the United States, the British and French Empires, the Netherlands, Belgium, Switzerland, Norway and Sweden, which in 
general carried on their foreign trade on a non-discriminatory basis and under relatively liberal treatment. It is true that Britain and France had established preferential relations within their empires, and that they and others in this group in a fair number of instances had obtained preferred positions in other countries, but by and large these nations conducted their foreign trade on the basis of liberal policies. The United States of course in recent years has been the nation which has held most steadfastly to sound commercial principles, and was at the outbreak of the war by all odds the leading exponent of the policies of commercial liberalism.

The second group, diametrically opposed to the first, consisted essentially of Germany and Italy. While Japan's commercial policy has had a definitely nationalistic bias it cannot be classed with that of Germany and Italy, for Japan has not in general employed the brutal methods of these countries to dominate foreign suppliers and markets. The same may be said of Russia even though Russia has made foreign trade a government monopoly.

The third group is an intermediate one, made up of a large number of economically weaker states, mainly in Central and Eastern Europe and in Latin America, which were compelled by the forces of the depression and through the insistence of other nations to control their exports and imports and to deal in preferences and discriminations, much in the same manner as the totalitarian states. There is, however, this important difference, that whereas Germany and Italy have followed these methods as a matter of national policy, the smaller states in the main did so unwillingly and because they had no alternative.

The principal contribution which the trade agreements policy has made to our national welfare centers around this deep conflict in trading purposes and methods. Because we were actively pursuing a policy of commercial liberalism and have constantly been advocating it to other countries, we have acted as a bulwark against the onward rush of the opposing methods. That the whole world did not, under the effect of the depression and the onslaught of totalitarian competition, abandon the principles of commercial liberalism is due more than anything else to the United States. This is a fact of unestimable value, not only as our trade has benefited thereby in the past, but because in it there lies a basis for the commercial reconstruction of the future.

So much for the past. The future holds the great task of reconstruction; of reestablishing order in a chaotic world and of creating conditions under which all nations can live.

The origins of the totalitarian states and of the present war, in the East as in the West, are to be found to an important extent in the fact that the victors of the First World War, the democratic states, built a system of trade restrictions and preferences in which it was difficult for the poorer nations to live. Today's tragic happenings are episodes in the age-old struggle between the haves and the have-nots and are at bottom, in part at least, uprisings against excessive economic nationalism. Precisely because of them it may be predicted that the world of tomorrow is not likely to be 
organized on the basis of the narrow economic nationalism which strangled the efforts at reconstruction made after the last war.

Just as no one can foretell when the present war will end, so no one can be certain today precisely what forces and what basic ideas will shape post-war international economic relations. The crux of the problem will lie, as it did in the period preceding the war, in the choice of trading methods, which in turn will be determined by the underlying policies of the principal trading nations.

The basic principles which, in the belief of the United States Government, should guide the policies of nations in the post-war world have recently been enunciated in the eight-point joint declaration of the President and Mr. Churchill at the historic meeting of the Atlantic. This set of basic principles, appropriately called "The Atlantic Charter," deals with commercial policy in its fourth point which reads:

They will endeavor, with due respect for their existing obligations, to further the enjoyment by all states, great or small, victor or vanquished, of access, on equal terms, to the trade and to the raw materials of the world which are needed for their economic prosperity.

The meaning and significance of this statement were described as follows by the Honorable Sumner Welles, Under Secretary of State, in an address delivered on October 7 last:

The basic conception is that your Government is determined to move towards the creation of conditions under which restrictive and unconscionable tariffs, preferences and discriminations are things of the past; under which no nation should seek to benefit itself at the expense of another; and under which destructive trade warfare shall be replaced by cooperation for the welfare of all nations.

The Atlantic declaration means that every nation has a right to expect that its legitimate trade will not be diverted and throttled by towering tariffs, preferences, discriminations, or narrow bilateral practices. Most fortunately we have already done much to put our own commercial policy in order. So long as we adhere and persistently implement the principles and policies which made possible the enactment of the Trade Agreements Act, the United States will not furnish, as it did after the last war, an excuse for tradedestroying and trade-diverting practices.

The purpose so simply set forth in the Atlantic declaration is to promote the economic prosperity of all nations "great or small, victor or vanquished." Given this purpose and the determination to act in accordance with it, the means of attaining this objective will always be found. It is a purpose which does not have its origin primarily in altruistic conceptions. It is inspired by the realization, so painfully forced on us by the experiences of the past and of the present, that in the long run no nation can prosper by itself or at the expense of others, and that no nation can live unto itself alone.

The principles relating to commercial policy which are embodied in the Atlantic declaration are those on which the trade agreements program has been based. Had it not been for the trade agreements, the declaration on commercial policy would have been impossible. Through the Atlantic declaration the commercial policies which the United States has followed since I934, and which found their principal expression in the trade agreements program, are made the basis for the post-war reconstruction. 